\title{
Wirusy umysłu i koncepcja piątej władzy. Przegląd i analiza nowych zjawisk komunikacyjnych $w$ Internecie
}

\begin{abstract}
Streszczenie
W niniejszym tekście dokonano przeglądu i analizy wirusouych zjawisk w Internecie, takich, które - działając jak supernova - uybuchają, zbierają wokół siebie zwolenników i przenikają na stałe do śuiadomości internautów. Ponadto przedstawiono autorską koncepcję „piątej władzy” znajdującej się w rękach internautów i przejawów sprawowania tejże na podstawie zgromadzonych materiałów. Jako metodę wybrano analizę jakościową za pomocą case studies. Stwierdzono, że mnogość zjawisk memetycznych u sieci jest ogromna, a zjawisko „piątej władzy” można uzasadnić empirycznie przez wnikliwą analizę ciekawych zjawisk komunikacyjnych dziejących się u sieci. „Piąta władza” ma ogromną siłę rażenia i, odpowiednio wykorzystana, stanowi potężne narzędzie.
\end{abstract}

Słowa kluczowe: memetyka, wirusy umysłu, piąta władza, Internet, internauci, case studies.

\section{Viruses of the mind and the concept of 'the fifth power'. Analysis and review of new communicational phenomena on the Internet}

\begin{abstract}
Review and analysis of viral phenomena on the Internet, which are explosive and attractive, and permanently penetrating the consciousness of the Internet users. The aim is also to present an original concept of 'the fifth power' in the hands of the internet, and the manifestations of the existence of that on the basis of collected materials. Case study analysis has been performed. A multitude of memetic phenomena in the network is huge, and the phenomenon of 'the fifth power' can be justified empirically through a thorough analysis of interesting phenomena taking place in the communications network. 'The fifth power' has an enormous firepower and if properly used, it can be an effective tool.
\end{abstract}

Keywords: memethics, viruses of the mind, the fifth power, the Internet, users, case studies. 


\section{Wprowadzenie}

Niniejszy tekst jest skróconą wersją pracy dyplomowej pt. „Wirusy umysłu. Koncepcja «piątej władzy», przegląd i analiza nowych zjawisk komunikacyjnych w internecie" napisanej pod kierunkiem dr hab. Teresy Sasińskiej-Klas, prof. Uniwersytetu Jagiellońskiego w 2015 roku. Praca traktowała szeroko o nowych zjawiskach komunikacyjnych $w$ Internecie, obfitowała w badania ilościowe i jakościowe, jednak ze względu na formułę i objętość artykułu skrócono obszar badawczy do analizy jakościowej case studies z uwzględnieniem kontekstu teoretycznego dotyczącego wyłącznie zjawisk wirusowych per se.

Niektóre z dziedzin i subdziedzin nauki mają to do siebie, że ich dokładne zrozumienie wymaga głębokiego „wyeksploatowania” tematu na podstawie dostępnych źródeł i zastanych sytuacji badawczych. W którymś momencie może jednak okazać się, że dotychczas zgromadzona wiedza na dany temat zaczyna powoli nie wystarczać do pełnego zrozumienia zjawiska, a uprzednio sklasyfikowane pojęcia czy wyznaczniki zdają się powoli „żyć swoim życiem”. Na bazie tego zjawiska poustaje więc potrzeba zagłębienia się $\mathrm{w}$ analizowane zagadnienie, pójścia o krok dalej. W przypadku, kiedy do czynienia ma się z materią tak plastyczną i dynamicznie zmieniającą się jak Internet, należałoby poszerzać zgromadzone informacje i aktualizować ich bazę równocześnie z wykładniczo przyrastającą liczbą nowych zjawisk i procesów komunikacyjnych zachodzących pomiędzy internautami.

Okazuje się bowiem, że oto Internet stawia kolejne wyzwanie - nowe zjawiska, poustające i zyskujące na popularności z rekordową prędkością, zdają się spełniać wymogi klasycznego memu opisanego przeze mnie w mojej pracy licencjackiej, jednak są materią tak rozłączną od memów (po przeprowadzeniu logicznej analizy przypadku), że trudno nie sklasyfikować ich i nie podzielić na nowo - szczególnie, że sami internauci zaczęli rozróżniać i nazywać poszczególne zjawiska. Podział na mem i viral dotychczas przeze mnie opisany - nie jest już wystarczający, jeśli weźmie się pod uwagę na przykład zjawisko internetowego „fejmu”, tak bardzo rozpouszechnione w ostatnim czasie.

Zachodzi obecnie potrzeba sklasyfikowania nowych zjawisk w kontekście zachowań społecznych, stąd koncepcja „piątej władzy”, czyli funkcji kontrolnej internautów. Mem w ujęciu Richarda Brodiego jest zjauiskiem nie tylko pouszechnym, ale wręcz nagminnym - za „zainfekowane” uważa on uszelkie sfery ludzkiego życia, czego wyraz dają nawet $w$ rozmowach, zachowaniach i stosunkach międzyludzkich jako takich. Praca ma za zadanie skonfrontować te hipotezy z pojęciem „piątej władzy”. Definicję stworzono specjalnie na potrzeby pracy, bowiem ilość ruchu, jaką generują wokół siebie zjawiska wirusowe, to coś, czego - będąc w obszarze nauk o komunikowaniu - zuyczajnie nie można pominąć. Widownia zbierająca się przed telewizorem w godzinach największej oglądalności to jedynie margines błędu w porównaniu z ilościami odsłon, odpowiedzi i „polubień”, jaką potrafią generować materiały w sieci. 
Często są to materiały, które z perspektywy „zuykłłego zjadacza chleba” mogą się wydawać szokująco wręcz... głupie.

Niniejszy artykuł przybliży więc charakterystykę memu jakiego takiego, a także w kontekście internetowych zjawisk określanych zbiorowo „memami”. Opisano również charakterystykę nowych zjawisk memetycznych $\mathrm{w}$ sieci $\mathrm{w}$ formie case studies, a także zjawisko „piątej władzy”.

\section{Wirusy umysłu}

Brodie określa wirusa jako „twór, który wykorzystuje zewnętrzne mechanizmy kopiujące, nakłaniając je do reprodukowania samego siebie" ${ }^{\text {. }}$. Mowa tutaj o wirusie jako takim, rozumianym z biologicznego punktu widzenia. Autor wprowadzenia do książki pt. Wirus umysłu, Tadeusz Niwiński, podkreśla, że, według niego, memy „chcą nas wykorzystać"2. Jako koncepcję ogólną wirusa umysłu można więc rozumieć zależność pomiędzy wirusem w biologicznym rozumieniu a memem (którego to definicja znajdzie się w kolejnym podrozdziale). Koncepcja ta jest wysoce istotna ze względu na wagę, jaką nadaje jej sam autor. Brodie pisze bowiem, że wirusy należy traktować poważnie, stanowią one bowiem najpotężniejszą z istniejących sił ${ }^{3}$. Argumentuje to faktem, że powielanie samego siebie - autoreplikacja - stanowi potężną moc, poróunuje ją również do mocy stwórczej, boskiej wręcz umiejętności do samostanowienia. Autor podkreśla, że fakt, iż „Bóg stworzył człowieka na swoje podobieństwo” jest znamiennym dowodem na samoreplikację. Można zatem rzec, że Bóg, w ujęciu Brodiego, to autoreplikant, innymi słowy - wirus umysłu, jak każdy inny.

Koncepcja Boga jako memu/wirusa jest znana w środowisku memetyków również Richard Dawkins traktuje o Bogu jako znakomitej, długofalowej i bardzo skutecznej formie memu. Z punktu widzenia Brodiego jest to jednak wirus umysłu, a nie mem. Ta subtelna różnica jest możliua do wychwycenia tylko w analizie konkretnych czynników, które wchodzą u skład definicji jednego i drugiego tworu.

Na bazie ogólnodostępnych materiałów autorstwa Brodiego można sformułować wniosek, że wirusem umysłu jest dowolne zjawisko, które replikuje się, przetwarza i posiada zdolność do samoreplikacji, przy czym wykorzystuje dostępne wokół nośniki - podobnie jak biologiczny wirus wykorzystuje organizm swojego nosiciela jako obszar, na którym zostanie dokonany podział i rozprzestrzenianie.

Brodie kategoryzuje wirusy u następujący sposób: uważa, że istnieją tzw. wirusy kulturowe, a także wirusy-wynalazki. Te pierwsze są wirusami stworzonymi w sposób naturalny, tj. wynikający z pierwotnych potrzeb człowieka bądź schematów poznawczych, jakie obowiązują uszystkich jednakowo. Można do nich zaliczyć na przykład potrzebę wiary w wyższy byt, tendencję do „plotkowania”, czyli - najprościej mówiąc

1 R. Brodie, Wirus umystu, tłum. P. Turski, Ravi, Warszawa 1997, s. 52.

2 T. Niwiński, Wprowadzenie: Kryzys umysłu [w:] ibidem, s. 7.

3 R. Brodie, op. cit., s. 51. 
- przekazywania nawzajem informacji o innych ludziach, a także tendencję do poutarzania, która jest naturalna i towarzyszy człowiekowi od zarania dziejów - to przez naśladounictuo dzieci uczą się móuić. Drugi typ wirusa to wynalazek. Zdaniem Brodiego jest to wytwór świadomie powołany do życia w określonym celu. Autor pisze, że na drodze życiouej spotyka się oba rodzaje wirusów, a oba prowadzą do tego samego skutku: ,jakaś część Ciebie samego bezwiednie odciąga Cię od zamierzeń i angażuje do pracy na rzecz wirusa"4.

Według Brodiego wirus umysłu jest potężnym i niszczycielskim narzędziem, choć sam autor nie neguje, że istnieje również szereg pozytyunych cech, które można wirusowi przypisać. Logika nakazuje uznać twór za doskonały, skoro posiada zdolność do samoreplikacji, doskonale się rozprzestrzenia i niejako „dba” o swój gatunek.

Podsumouując, wirusem umysłu nazwać można nie tylko to, co samoczynnie się powiela, posiada zdolność do samoreplikacji i przetuarza się, mutuje czy rozprzestrzenia, lecz również to, co posiada zdolność „uładania” ludzkim umysłem; co zajmuje miejsce u umyśle, wpaja się, nakazuje zmieniać tok rozumowania, postępowania, co odrywa nas od wykonywanej czynności na rzecz zrobienia czegoś zupełnie innego. To zjawisko, które posiada moc sprawczą do zmieniania ludzkich postaw - wirus posiada zatem szereg „umiejętności”, które nakłaniają człowieka do prac na jego korzyść. Korzyścią dla wirusa jest rozsyłanie go dalej w niezmienionej bądź zmodyfikowanej formie. Trudno opisać to bez animizacji, jednak przykłady z ,internetouego podwórka" dobitnie rozjaśnią tę koncepcję.

Nieco pesymistyczna wizja wirusów umysłu w ujęciu Brodiego zakłada, że ich siła polega na pewnej formie programowania zachowania ${ }^{5}$. Brodie twierdzi, że wirusy-wynalazki, czyli idee zaprogramowane w pewien ustalony sposób, mający na celu propagowanie ich za pomocą memów wśród społeczeństua, poustały na przełomie ostatnich dziesięcioleci i powoli „zbierają żniwo”. Autor uważa, że u pieruszej kolejności wirusy-wynalazki, jako fenomen przyszłości, muszą stoczyć bój z wirusami kulturouymi, czyli zakorzenionymi typologiami, wedle których całe społeczeństwa żyły na przestrzeni wieków.

Nie jest istotne, co konkretnie Brodie definiuje jako wirusy-uynalazki (choć jest to np. marketing wielopoziomouy, czyli rodzaj marketingu, w którym sprzedaje się produkt przez techniki - można by rzec - umiarkowanie etyczne, co nie stanowi idei tej pracy), istotnym jest fakt uspomnianej „batalii”, jaką muszą stoczyć uspomniane wirusy. Logicznym wydaje się stwierdzenie, że coś trzeba usunąć, żeby na to miejsce mogło wejść coś innego - tak Brodie rozumie ideę wirusów umysłu.

Jego dość „apokaliptyczna” wizja wiąże się z faktem, że ocenia je przez pryzmat globalny - wyrywkowo analizuje rzeczywistość, szukając potwierdzenia swoich tez i przedstawia argumenty, które pesymistycznie nastrajają odbiorcę wobec koncepcji wirusa umysłu. Brodie pisze, że wirusy ze swoją siłą rażenia prawdopodobnie znajdą

\footnotetext{
4 Ibidem, s. 54.
}

5 Ibidem, s. 183. 
się w rękach ludzi chcących zdobyć władzę i pieniądze - wyraża jednak cień nadziei, że znajdzie się ktoś, kto użyje wirusów u sposób etyczny i doskonały, korzystając z ich siły umiejętnie.

W niniejszej pracy zostaną zaprezentowane oba te stanowiska, a jednocześnie oba zostaną zanegowane - swoisty „kot Schroedingera” ${ }^{\text {w }}$ wynika bowiem z faktu, że Internet i internauci stanowią materię wywijającą się z konwenansów, co dobitnie przedstawia klasyczny model komunikowania Harolda Lasswella wraz z porównaniami go do klasycznych wyznaczników komunikowania w sieci. Internetowe wirusy umysłu stanowią bowiem zarówno odzwierciedlenie, jak i negację postawionych przez Brodiego tez.

Brodie uważa, że psychologia ewolucyjna jest kluczem do zrozumienia idei wirusów umysłu - stawia on pytanie: „Czy będziemy biernie ewoluować, miotani chaotyczną selekcją naturalną, nie uwzględniającą naszego szczęścia, zadowolenia ani duchowości, czy też weźmiemy ster naszej ewolucji w swoje ręce i sami nadamy jej odpowiedni kierunek?"? Pytanie, z punktu widzenia tej pracy, uznać można za bezzasadne, co postaram się udowodnić w kolejnych podrozdziałach. Trudno bowiem analizować przestrzeń opartą stricte na mechanizmach ewolucyjnych pod kątem mocy sprawczej społeczeństua - jeśli bowiem określa się coś jako namiastkę procesu ewolucji, to trudno mówić o „braniu we własne ręce”, skoro wirusy żyją własnym życiem i tak wymkną się spod kontroli. Nie chodzi tutaj o „magiczne” zdolności samoreplikacyjne, bowiem to ludzie biorą udział w powielaniu i modyfikacji wirusów, jednak z perspektywy ludzkości jako zbiorowości można stwierdzić, że wirusy żyją i ewoluują jak najbardziej swoim życiem.

Internet jest płaszczyzną chaotyczną i niezorganizowaną, jednak - jak uspomniany kot Schroedingera - przejawia jednocześnie pewne interesujące własności, dzięki którym paradoksalnie łatwo poddaje się kategoryzacji. Niniejsza praca ma za zadanie przedstawić, $\mathrm{w}$ których obszarach Brodie pomylit się ze swoją oceną wirusów umysłu, a gdzie miał rację. Choć obie te kwestie są subiektywnym odczuciem autorki, świadczą jednak dobitnie o dyskursywności przestrzeni internetowej jako takiej.

\section{Memy}

Najprościej rzecz ujmując, mem można zdefiniować na podstawie definicji Glenta Granta, zgodnie z którą mem to „zaraźliuy wzorzec, który replikuje się zarażając ludzki umysł i niejako zmusza do powielania tegoż wzorca"8. Najważniejszą i najznamienitszą

\footnotetext{
6 Słynny w mechanice kwantowej eksperyment myślouy, w wyniku którego poustał paradoks polegający na tym, że kot umieszczony w pojemniku przy pewnych kwantouych okolicznościach i losouej możliwości pozostania żyuym bądź martuym, pozostaje jednocześnie martuy i żywy. Paradoks ten funkcjonuje w popkulturze pod takim właśnie hasłem.

7 R. Brodie, op. cit., s. 12.

${ }^{8}$ G. Grant, Memetic Lexicon, przekład własny, http://pespmc1.vub.ac.be/MEMLEX.html [dostęp: 23.04.2013], na podstawie M. Litman, FenoMEM, czyli charakterystyka internetowych
} 
definicją memu zdaje się jednak definicja sformułowana przez Richarda Dawkinsa, według której mem oznacza najmniejszą jednostkę ewolucji kulturowej ${ }^{9}$. Jest to analogia do biologicznej teorii ewolucji, gdzie najmniejszą jednostką jest gen. W tym duchu utrzymana jest cała filozofia Dawkinsa, bowiem uyróżnia on cechy analogiczne do genu - dla memu. Dla tematyki, o której mowa, najbardziej trafną definicją będzie ta, uprzednio sformułowana przez autorkę tego artykułu:

mem to poutarzany schemat, wirus, przeskakujący przez rzeszę pokoleń i widoczny w ramach najróżniejszych kultur na przełomie różnych okresóu czasouych - od «krótkotruałych» memów istniejących przez okres kilku miesięcy czy lat, po memy utrzymujące się na przełomie tysiącleci ${ }^{10}$.

Dawkins twierdzi, że mem - tak samo jak gen - działa na zasadzie doboru naturalnego, a replikują się wyłącznie silne i „dobrze przystosowane” memy, które truale osadzają się w ludzkich umysłach. Dawkins uważa róunież, że „od wierności kopiowania ważniejsza jest długowieczność memu" ${ }^{\prime 1}$, co stanowi ważny postulat $w$ rozważaniach o wirusach umysłu. W przypadku memów internetowych - o czym mowa u pracy pt. FenoMEM, czyli charakterystyka internetowych memów ${ }^{12}-$ nie jest wysoce istotna zgodność memu z oryginałem, jednak ważne jest spełnianie kryteriów, które dany mem obowiązują. Ważniejszy jest sam proces ewoluowania i przekształcania memów, które zyskują nową atrakcyjność, a dzięki temu są lepiej przyswajane i przetwarzane przez użytkouników.

Można więc ująć, że mem to jednostka, która u procesie powielania może - ale nie musi - zmieniać się i modyfikować, winna jednak posiadać konkretne kryteria, które pozwolą jej na replikowanie się w określonym środowisku. Replikowanie, czyli przesyłanie, roznoszenie, przekazywanie, oznacza, że wszelkie formy ruchu, zarówno wertykalne, jak i horyzontalne, są replikacją.

Mempleks jest - najprościej określając - zbiorem memów, konkretną pulą, w skład której wchodzą memy tej samej bądź różnych kategorii - pozostające jednak w ścisłej korelacji między sobą. Korelacja ta tworzy się samoczynnie bądź zainicjowana jest przez twórcóu mempleksu (jak ma się to w przypadku memów internetowych).

Susan Blackmore, będąca niejako „następczynią” czy też wierną naśladouniczką Dawkinsa, podkreśla, że „replikator kulturowy musi posiadać współczynnik naśla-

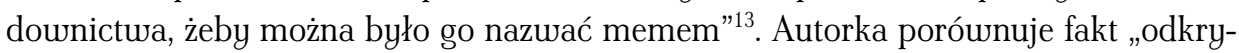

memów, praca licencjacka napisana pod kierunkiem dr Magdaleny Hodalskiej, Instytut Dziennikarstua i Komunikacji Społecznej Uniwersytetu Jagiellońskiego, Kraków 2013, s. 9.

9 R. Dawkins, Samolubny gen, tłum. M. Skoneczny, Prószyński i S-ka, Warszawa 2002, s. 146.

10 M. Litman, op. cit., s. 10.

11 R. Dawkins, op. cit., s. 147.

12 M. Litman, op. cit.

13 S. Blackmore, Maszyna memowa, tłum. N. Radomski, Rebis, Poznań 2002, s. 29. 
cia" memów do największych odkryć ludzkości. Współczynnik naśladounictua jest wyznacznikiem, który definiuje, czy u ogóle ma się do czynienia z memem jako takim - również ona, podobnie jak Dawkins, nie uznaje wyższości zgodności kopiowania nad samym faktem powielania i naśladownictua.

Magdalena Litman uyróżnia kilka wyznaczników, którymi muszą odznaczać się internetowe zjawiska, żeby mogły zyskać miano memu. Wprowadza rozróżnienie na mem i viral, czyli wirusowe zjauisko niebędące do końca memem, noszące jednak znamiona zjawiska replikującego się na identycznych zasadach. Przyjmuje, że:

Podsumouując i upraszczając - na podstawie własnych obserwacji mogę sformułować, że viralem jest:

- Forma internetowa rozprzestrzeniająca się $\mathrm{w}$ formie ciekawego czy żartobliwego filmu video bądź utworu muzycznego; przesyłana między użytkounikami w ramach podzielenia się informacją, sensacją czy dowcipem w niej zawartym.

- Forma, w której zmienianie elementów przez internautów nie musi być intertekstualne (jak w przypadku memu), bądź taka, gdzie zmiana elementów nie jest możliwa, bo «zepsuje» konwencję pierwotną - viral może być jednak parodiowany.

Mem zaś, wedle uniosków własnych na podstawie obserwacji i informacji zebranych w Internecie, charakteryzować będzie:

- Intertekstualność - mem zawsze nawiązuje do jakiejś idei, niezależnie od stopnia związku między znaczącym a znaczonym. Może to być wyrażone jako pastisz bezpośredni - tj. taki, który wyśmiewa konkretną osobę bądź zjawisko znajdujące się jako centralny obiekt na obrazku, bądź taki, który wyśmiewa topos lub kanon pewnych zachowań, którym przypisuje się jakiś symbol zaproponowany przez danego internautę, a zaakceptowany przez pozostałych.

- Mem musi dać się modyfikować z zachowaniem pierwotnej konwencji - skoro tworzy się obrazek będący ucieleśnieniem przywar narodouych Polaków, to nie można przerobić go na formę wyśmiewającą wady Włochów, gdyż obrazek przypisany «polskości» nie zda egzaminu przy opisywaniu «włoskości» - a to ze względu na akceptację konwencji przez użytkouników i przyswojenie idei pierwotnego obrazka.

- Owo miksowanie i przerabianie musi opierać się na zasadach ustalonych przy pierwotnym powstaniu memu, stąd popularność formy obrazkowej, którą zmodyfikować można łatwo - np. poprzez dodanie napisu.

Podsumowaniem całego konceptu jest wniosek, że mem opiera się głóunie na MODYFIKOWANIU i przesyłaniu, a viral na PRZESYŁANIU konkretnej informacji. Nie oznacza to jednak, że przesyłana interpretacja memu automatycznie zmienia się w viral - chodzi o genezę poustania danej informacji i okoliczności, do jakich się ją głównie «stosuje» ${ }^{14}$.

Na potrzeby tego tekstu, definicje i podziały dotyczące memów i virali wydają się wyczerpujące i zasadne. Istotą są bowiem przedstawione dalej wyszczególnienia i analizy własne, na których opiera się wspomniana w tytule koncepcja „piątej władzy”.

14 M. Litman, op. cit., s. 22-23. 


\section{Piąta władza}

Koncepcja piątej władzy jest terminem stworzonym przez autorkę tekstu. Źródłosłowu pojęcia należy doszukiwać się w naukach politycznych - termin został bowiem stworzony na podstawie terminu „Czwarta władza”, jakim określa się wolne media w demokratycznych państwach. „Piąta władza”, w ujęciu definicji realnej, to kolejna, następująca po czwartej forma władzy. Definicja nominalna przedstawia piątą uładzę rozumianą jako kolejny organ obok władzy ustawodawczej, wykonawczej, sądowniczej i mediów, które nadzorują trzy uprzednio uymienione organy władzy. Za definicję operacyjną można uznać tę, że piątą władzę definiują działania internautów zogniskowane na nadzór i kontrolę wszystkich dziedzin życia, przy jednoczesnym przekazywaniu informacji w sposób wirusouy i mający na celu zaszczepienie konkretnych idei w umysłach odbiorców, którzy pozyskane informacje przekażą dalej.

Innymi słowy, piąta władza to kolejna odsłona rodzaju władzy społecznej, a jej szczególnym przejawem są wirusowe działania internautów. Różni się ona jednak od czwartej władzy wieloma aspektami. Wśród nich można wymienić między innymi to, że władza ta nie stanowi wyłącznie funkcji kontrolnej (jaka przysługuje mediom), ani komentatorskiej czy orzekającej. Władza ta ma za zadanie zmianę ludzkiego postrzegania, percepcji czy poglądu na jakiś temat, co z kolei łączy ją nieuchronnie z koncepcją wirusów umysłu Richarda Brodiego. Analizując piątą władzę, nie mamy na myśli wyłącznie racjonalnej i realnie przyczyniającej się do rozwoju społeczeństwa funkcji mowa tu róunież o szeregu funkcji okołorozrywkowych, gdzie nadal zostają spełnione uymienione wcześniej kryteria.

Można przyjąć, że najważniejszym zadaniem piątej władzy jest komentowanie i tłumaczenie obserwowalnych w sieci zjawisk. Chodzi tu zarówno o zjawiska typowo rozrywkowe, jak i sprawy wagi państwowej, a także szereg mód i pomniejszych zachowań społecznych, które dopiero zdefiniowane przez internautóu zaczynają nabierać mocy sprawczej. Piątą władzą jest zatem władza internautów - to oni stanowią gigantyczną siłę, zarówno reklamową, jak i opiniotwórczą; to oni generują okresowe mody i trendy, oni pilnują czwartej uładzy; to w Internecie najbardziej przekrojowo prezentują się idee i wartości społeczeństwa ponowoczesnego.

Mnogość zjawisk memetycznych w sieci siłą rzeczy doprowadziła do poustania wirusów umysłu, czyli idei żyjących własnym życiem, mających niebywałe zdolności replikacyjne i będących idealnym „narzędziem” do przekazywania licznych treści, zarówno komercyjnych, jak i rozrywkowych, a także tych o wyższym znaczeniu w rozumieniu wartościouania u społeczeństuie, gdzie rozrywka stanowi dalszy plan, a za wartości nadrzędne przyjmuje się dbanie o dobro ojczyzny, komentowanie aktualnych wydarzeń itd.

Piąta władza ma ogromną siłę rażenia. Za szczególny przykład siły piątej władzy można uznać fakt, że Janusz Korwin-Mikke, lider partii Nowa Prawica w Polsce, niecieszący się do tej pory wielkim zainteresowaniem ze strony społeczeństua, po raz 
pierwszy od durudziestu trzech lat przekroczył granicę progu uyborczego, podczas uyborów do Europarlamentu u 2014 roku i został wybrany na eurodeputowanego na najbliższą kadencję Parlamentu Europejskiego. Na mocy koncepcji piątej uładzy można zachowawczo przyjąć, że było to spowodowane działaniami - pozornie błahymi - zainicjowanymi ze strony internautów. Materiały badawcze i case studies pokażą, że pozornie rozrywkowe i humorystyczne mempleksy potrafią mieć ogromną siłę oddziaływania i - w myśl zasady wirusowej - potrafią wpłynąć na gusta i percepcję odbiorców. Pozornie zabawne i rozrywkowe powielanie wizerunku Korwin-Mikkego jako „zabawnego reformatora” mogło się przyczynić do jego sukcesu w ostatnich wyborach do Europarlamentu. Piąta władza w pełni zasługuje na miano „władzy” ze względu na swoją moc sprawczą, co zostanie udowodnione w kolejnych rozdziałach. Sama ilość udostępnień materiałów „sprawujących piątą władzę” wskazuje na fakt, że może ona realnie zaszczepiać idee w umysłach wielu osób jednocześnie.

\section{Case studies}

W rozważaniach dotyczących nowych zjawisk wirusowych należy uwzględnić głównie takie, które z czysto technicznego punktu widzenia osiągają sukces memetyczny. Ten punkt widzenia oznacza popularność w sieci, mierzoną na zasadzie punktu odniesienia, przykładowo - jeżeli dany film w serwisie YouTube posiada ok. 500 odsłon, a inny film - półtora miliona, oznacza to ze statystycznego punktu widzenia, że ten drugi jest bardziej popularny. W dalszej części tekstu zanalizowano kilka takich zjawisk, które lawinowo zebrały wokół siebie liczne grono internautów.

Zjawisko „fejmu” (od angielskiego terminu fame - sława) jest czymś, czego nie można pominąć przy rozważaniach na temat wirusów. Jest to nietypowy, nieklasyczny przykład, który nie jest ani memem, ani viralem, jednakowoż nie można nie zauważyć, że jest wynikową memetycznego sukcesu. Krótko mówiąc - fejm (na potrzeby pracy używana będzie spolszczona nazwa, tak bowiem potocznie określa się zjawisko w przestrzeni internetowej) to nic innego jak sława, zdobyta jednak inną, niż dotychczasowe, możliwą drogą. W nauce opisano już zjawisko celebrytów, czyli „osób znanych z tego, że są znane"15. W całym procesie rodzenia się celebrytów absurdem był fakt, że są to nierzadko osoby nieuyróżniające się żadnym specjalnym talentem czy umiejętnością, a ich popularność polega na „widzialności” w mediach, co staje się samonapędzającą się machiną. Te krótkie przypomnienie ma za zadanie pokazać, że uspółcześni użytkownicy sieci wykształcili nowe, jeszcze bardziej kuriozalne zjawisko zwane fejmem jest to pogardliwe, lekceważące określenie człowieka, który stał się popularny u sieci za sprawą pewnych okoliczności.

Należy podkreślić, że nie są to tzw. guiazdy Internetu, takim terminem określa się bowiem różnego rodzaju ekstrawaganckie persony, które przez swoje zachowanie

15 W. Godzic, Znani z tego, że są znani. Celebryci w kulturze tabloidów, Wydaunictwa Akademickie i Profesjonalne, Warszawa 2007, s. 21. 
(np. film czy wypowiedź) stają się okresowymi „gwiazdami”, o których dyskutuje się w pogardliwym czy prześmieuczym tonie. Fejmem jest bowiem osoba, której życie jest śledzone na bieżąco i posiada ona autentycznych fanów (czy może zuolenników), a jej życie przypomina życie celebryty, tyle że początek sławy bierze się z innego źródła niż u przypadku gwiazd szklanego ekranu. Celebryta jest osobą, którą chętnie interesują się media (jako przykład - „Miss Euro 2012”, modelka Natalia Siwiec, która przez ściągnięcie uwagi paparazzich na stadionie przedostała się do medióu mainstreamowych i figuruje jako polska celebrytka). Fejmem zaś jest osoba, która, z reguły, nie wychodzi poza internetowe ramy, jednak ilość fanów i osób zaangażowanych w jej życie jest porażająca.

Warto dodać, że mowa tu o społecznościach młodzieżouych (12-20 lat), przy czym znaczna część fejmóu to osoby poniżej 18 roku życia. Przykład portalu Ask.fm idealnie obrazuje strukturę powstawania internetowej sławy nastolatków, dlatego też ten portal zostanie przedstawiony jako najbardziej obrazowy.

Ask.fm to serwis pochodzenia łoteuskiego (obecnie własność irlandzka), którego zamierzenie jest bardzo proste - pytania i odpowiedzi. Użytkounicy mają możliwość założenia własnego konta (pod nazwiskiem bądź pseudonimem), a inni użytkounicy mogą zadawać pytania - również pod nazwiskiem, pseudonimem, albo całkowicie anonimowo, bez logowania się do serwisu. Oznacza to, że każdy użytkownik „z ulicy” może zadać pytanie użytkounikowi Aska. Portal poustał w roku 2010 i zyskał ogromną popularność wśród młodzieży - obecnie strona znajduje się na 213 miejscu wśród wszystkich stron internetowych na świecie, których liczbę szacuje się na półtora miliarda ${ }^{16}$.

W trakcie roku 2013 na polskich łamach portalu zainicjowano zjawisko, które obowiązkowo należy zaliczyć do zjawisk wirusouych - niektóre osoby posiadające konta u serwisie zaczęły z jakichś powodów stawać się „trendy” i zyskiwać grono wielbicieli - co w praktyce oznacza, że jednym nastolatkom przyglądała się ogromna grupa innych. Kilkanaście osób zyskało wyniki oglądalności, które nawet jak na internetowe standardy wydają się nieuyobrażalne - można tu zaliczyć między innymi 19-letniego Łukasza Waurzyniaka - chłopaka, który nie jest ani muzykiem, ani tancerzem. Jest zuyczajnym nastolatkiem, którego sposób odpowiedzi z jakichś przyczyn stał się atrakcyjny dla innych użytkouników. Obecnie na koncie chłopaka znajduje się ponad 72 miliony „polubień” (opcja analogiczna do „lajków” na Facebooku), co oznacza, że nastolatkowie 72 miliony razy kliknęli „podoba mi się to” przy jego odpowiedziach $^{17}$.

Aleksandra Szepczyńska - studentka z Krakowa - rozpoczęła swoją działalność na portalu w wieku 18 lat - obecnie może pochwalić się wynikiem 22 milionóu polubień własnego profilu ${ }^{18}$, a jej działalność u sieci polega głównie na relacjonowaniu suojego

16 http://www.alexa.com/siteinfo/ask.fm [dostęp: 22.01.2015].

17 http://ask.fm/lukaswawrzyniak [dostęp: 22.01.2015].

18 http://ask.fm/poziom [dostęp: 22.01.2015]. 
życia, ustawiania zdjęć ubioru i odpowiadania w ironiczny sposób na zadawane jej przez użytkowników pytania. Przykładowe pytanie potrafi osiągnąć 30 tysięcy polubień jednorazowo, co jest kolosalnym wynikiem - nawet w odniesieniu do internetowych standardów.

Nierzadko fejmami stają się wręcz dzieci - przykładem może być 15-latka o pseudonimie Henzai, która regularnie zmienia nazuy na portalu, co „resetuje” jej licznik polubień. Nie ma to jednak znaczenia, bowiem na hasło „henzai” wyszukiwarka Google pokazuje... 100 tysięcy wyników. Istnieją dziesiątki nastolatków, które zdobyły „sławę" w ten sposób - cudzysłów nie jest przypadkowy, trudno bowiem mówić o „sławie” w wirtualnym ujęciu. Jeżeli jednak ta „sława” przekłada się na gigantyczne ilości osób, dla których dana postać jest rozpoznawalna, można już mówić o realnej sławie, która - z racji swojego pochodzenia - pogardliwie nazywana jest fejmem. Nietrudno jest zrozumieć, dlaczego jedni nastolatkowie są bardziej popularni niż inni oczywistym jest, że ilość zdjęć drogich gadżetów czy pogardliwy, buntowniczy ton uspomagają tworzenie się uspomnianej popularności.

Największymi fejmami są osoby, których kontrowersyjny styl bycia (palenie papierosów i picie alkoholu przez małoletnich zdecydowanie „poprawia” wyniki) imponuje innym nastolatkom, z - być może - mniejszą siłą przebicia. Nie jest jednak istotny aspekt psychologiczny zjawiska, z punktu widzenia pracy ważne jest to, że nastolatkowie (bądź - nie bojąc się określenia - dzieci) bez jakiejkolwiek wiedzy na temat memetyki czy wirusowego przekazywania informacji potrafią intuicyjnie, na bazie obserwacji, dostosować swój tryb bycia i przedstawianie swojej osoby u taki sposób, aby osiągnąć wymierną, wirtualną sławę. Najbardziej lubianymi odpowiedziami stają się więc te, które zawierają dużą dawkę przekleństw, szyderczych komentarzy dotyczących osób/rzeczywistości, a także zdjęcia - szczególnie te z wyzywającym makijażem, kolczykami czy tak upragnioną i cenioną przez młodzież najnouszą elektroniką. Portal Ask.fm wzbudza ogromne kontrowersje, głównie przez fakt, że odnotowano kilka przypadków samobójstw popełnionych przez nastolatków, dla których ewidentnym punktem zapalnym była obecność na portalu ${ }^{19}$. Brytyjski premier David Cameron nawołuje do bojkotu strony, a psychologowie na całym świecie zastanawiają się nad genezą nienawiści płynącej ze strony jednych nastolatków w kierunku innych. Oczywistą przesłanką jest fakt, że portal umożliwia u pełni anonimowe skomentowanie osoby, a w środowisku nastolatków zjawisko „hejtingu” (czyli internetowej mowy nienawiści) jest wysoce popularne.

Memetyka jednak odnajduje tutaj drugie dno - faktem jest, że uspomniane nastolatki w jakiś sposób osiągają wirusouy sukces, bowiem treści, które wrzucają, zaczynają w peunym momencie żyć suoim życiem - gdyby wirusowo przesyłane treści generowały sobie sukces jako taki (np. czyjeś zdjęcie stałoby się ważniejsze niż jego osoba), to można by mówić o klasycznym memie. Nie dzieje się tak jednak, bowiem to

19 http://natemat.pl/71559,zamknijcie-portal-ask-fm-nie-chce-patrzec-na-smierc-kolejnych-dzieci-dramatyczny-apel-matki [dostęp: 22.01.2015]. 
osoba zostaje „memem”, a u zasadzie jej kreacja internetowa. Nie można zatem uznać, że jest to mem u klasycznym ujęciu, nie można również stwierdzić, że nie jest to zjawisko wirusowe. Na bazie obserwacji osób z portalu można sformułować następujące unioski, że fejmem u przestrzeni internetowej jest osoba, która:

- staje się popularna uyłącznie dlatego, że jest popularna;

- jej profil jest wirusowo przekazywany sobie przez użytkowników, a jej imię bądź pseudonim staje się „marką” rozpoznawalną przez innych użytkowników;

- nie posiada specjalnych uzdolnień ani oczywistych talentów, które przynoszą sukces na przykład guiazdom muzyki czy sportu;

- $\quad$ ma jednak pewien rodzaj specyficznej charyzmy, na mocy której inni użytkounicy chętnie interesują się jej życiem;

- nie jest zainteresowana sławą jako taką - jej popularność jest czysto przypadkowa, determinowana wyłącznie odgórnymi czynnikami.

Ostatni punkt jest kontrowersyjny, jednak tak naprawdę niewielki odsetek fejmów z portalu Ask.fm swoją „sławę” zdobyło w sposób celowy - większość jest bowiem znana z przypadku (albo ze względu na swój sposób bycia czy wygląd) - jeżeli bowiem użytkounicy wyłapią, że osoba jest „łasa na sławę”, zostaje ona automatycznie wyśmiana, a wyłudzanie zainteresowania spotyka się z krytyką bądź otwartą, brutalną nienawiścią i wyśmiewaniem.

Trzeba jednak przyznać, że kilkudziesięciu nastolatków „wypłynęło” z przestrzeni pozornie nieznanego nikomu portalu i obecnie ich profile w bardziej znanych serwisach (jak np. Facebook) cieszą się ogromnym powodzeniem. Pamiętać jednak należy, że to Ask.fm stanowił kolebkę ich popularności, a źródłem nie było nic, co - w obiegowym rozumieniu - przynosi człowiekowi sławę (talent, umiejętności itd.).

To kolejny przykład, że współczesny Internet kreuje wirusowe zjawiska, które wymykają się z wcześniej opisanych konwenansów - popularność liczona w milionach polubień nie jest przecież zjawiskiem marginalnym i nie może zostać niezauważona. Jest faktem, który pokazuje, że wirusy umysłu pojawiają się u najmniej spodziewanych miejscach i odnoszą ogromne sukcesy - z liczbowego punktu widzenia.

Innym zjawiskiem wirusowym są copypasty. Termin „copypasta” poustał w wyniku połączenia dwóch słów oznaczających z angielskiego „kopiuj” (copy) oraz „wklej” (paste). W najkrótszy z możliwych sposób, zdefiniować go można jako szablon, kalkę językową, formę cliche używanego podczas różnego rodzaju internetouych dyskusji ${ }^{20}$. Ciekawostką jest, że ten twór nie musi pasować do kontekstu dyskusji, nie są to zatem gotowe szablony rozmowy, a jedynie formy memów, które powodują zaburzenie toku rozmouy i stanowią element humorystyczny dla „wtajemniczonych” użytkowników. Jest to zatem kolejny przykład formy rozrywkowej, która także zyskuje na popularności.

Czym w praktyce jest copypasta? Istnieje kilka rodzajów tekstów kopiowanych jako szablon. Ich głównym celem jest rozśmieszenie innych użytkowników, ale także

20 http://pl.copypasta.wikia.com/wiki/Strona_g\%C5\%82\%C3\%B3wna [dostęp: 21.01.2015]. 
zaprezentowanie pewnej przynależności - do grupy „wtajemniczonych” internautów, którzy znajdują te teksty i świadomie wykorzystują jako żart.

Przykładem copypasty jest tekst roboczo zwany „Czy ty masz w ogóle rozum i godność człowieka?", który przeniknął do świadomości internautów. Jest to tekst anonimowego użytkownika, który wygląda na autentyczny uyraz oburzenia treściami przez niego zastanymi.

Komentarz był wirusowo przesyłany wśród internautów do takiego poziomu, że zaczął być w końcu traktowany jako pewien symbol - w tym wypadku symbol wyszydzenia czyjegoś podejścia do tematu. Copypasta wygląda następująco (fragment, pisounia oryginalna):

no i ja się pytam człowieku dumny ty jesteś z siebie zdajesz sobie sprawę z tego co robisz?masz ty wogóle rozum i godnośc człowieka?ja nie wiem ale żałosny typek z ciebie ,chyba nie pomyślałes nawet co robisz i kogo obrażasz ,możesz sobie obrażac tych co na to zasłużyli sobie ale nie naszego papieża polaka naszego rodaka wielką osobę ,i tak wyjątkowa i ważną bo to nie jest ktoś tam taki sobie że możesz go sobie uyśmiać bo tak ci się podoba nie wiem $\mathrm{w}$ jakiej ty się wychowałes rodzinie ale chyba ty nie wiem nie rozumiesz co to jest wiara... ${ }^{21}$.

Komentarz w oryginale jest kilkakrotnie dłuższy i jest wyrazem oburzenia, że ktoś z internautów obraził osobę Jana Pawła II - najpewniej przez niewybredny dowcip. Komentarz jest wyszydzany ze względu na jego długość, a także na wyjątkowe - jak na Internet - zaangażowanie tematem oraz ewidentny brak zachowania zasad poprawnej pisouni. Komentarz jest wklejany do innych dyskusji (bez podpisywania, że jest to skopiowanie czyichś słów), co w pierwszej chwili - dla niezaznajomionych użytkowników - wygląda, jakby osoba komentująca rzeczywiście oburzała się z powodu obrazy papieża Polaka. Jest to kuriozum, bo cały „doucip” polega na tym, że komentarz wkleja się przy rozmowach o czymś zupełnie innym - poustaje wówczas szum komunikacyjny, gdzie niektórzy użytkownicy z niedowierzaniem pytają, dlaczego ktoś zdecydował się na taką formę wypowiedzi, inni zaś - ci „zaznajomieni” - przekazują wyrazy uznania za trafnie wyrażony dowcip.

Jest to zatem ironia, mem słowny, który - mimo że nie stanowi formy obrazkowej - spełnia uszystkie uytyczne memu przytoczone na początku tego tekstu. Istnieje wiele innych copypast, większość z nich jest albo faktycznym komentarzem kogoś, kto nie zachował zasad pisowni i uyraził się w niefortunny sposób, albo absurdalnym, dziwacznym tekstem wymyślonym na potrzeby kopiowania.

Niektóre copypasty są szokująco dziwaczne - opisują bowiem „perypetie” użytkounika, który „spotkał” na przykład Wojciecha Cejrouskiego bądź inną medialną osobę, po czym nastąpiły różne absurdalne wydarzenia:

${ }^{21}$ http://wuw.wykop.pl/upis/4133273/masz-ty-w-ogole-rozum-i-godnosc-czlowieka-\%CA\%96-humor/ [dostęp: 22.01.2015]. 
Cejrouski u śmiech i mówi, że boso to on chodzi w eleganckich krajach zagranicznych a nie w Polsce gdzie co 5 metróu można u psie gówno wejść albo jakąś strzykawkę z HIV, i że po Polsce to on chodzi w porządnych butach i pokazuje mi swoje buty z jakimiś frendzlami, paskami, dolce\&gabana i że nawet taki guzik mają, że jak go lawina przysypie u tych butach to on ten guzik naciska i go wtedy można znaleźć pod śniegiem² ${ }^{22}$

Jest to tylko fragment, bowiem cała copypasta jest kilkanaście razy dłuższa - opowiada absurdalną historię jakoby Wojciech Cejrouski kazał internaucie wyrzucić jego buty do śmietnika, a następnie wyjął je, założył i uciekł. Cały komizm tekstu polega na tym, że pisany jest u przekonujący, relacjonujący wręcz sposób - inne copypasty „idą za ciosem", są więc pisane równie reporterskim językiem, przez co można początkowo odnieść wrażenie, że czyta się praudziwą relację z przygody internauty. Dopiero absurdy, stopniowo wypływające z tekstu, zaczynają wskazywać na pewien „wkręt”, czyli - innymi słowy - daliśmy się nabrać.

Taka copypasta jest umieszczana przez różnych użytkowników w totalnie niepowiązanych ze sobą tematycznie dyskusjach, na przykład w komentarzach na forum kulinarnym. Jeżeli copypastę napotka osoba niezaznajomiona z tematem, zaczyna odczuwać dysonans i dopytywać o sens takich opowieści, fundując jednocześnie rozrywkę innym użytkownikom. Nie ma to głębszego - poza rozrywkowym - celu, jednak ewidentnie jest formą memetyczną (replikuje się, samopowiela, wśród copypast są gorsze i lepsze, które odnoszą sukces, bowiem znajdują się w wielu miejscach w sieci jako komentarz). Użytkownicy są „nosicielem” copypast, ponieważ przeklejają je z własnej woli, wiedzeni wyłącznie dostarczeniem rozrywki innym użytkounikom i zapewnieniem sobie chwilowego prestiżu jako osoby błyskotliwej, obeznanej w internetouych kalkach i zabawnej.

Podsumouując, copypasta to mem słowny, czyli coś, co służy do komentowania rzeczywistości w sposób skompresowany. Wklejenie długiego wywodu na absurdalny temat pod czyjąś wypowiedzią pokazuje ironiczny doń stosunek i wyśmieua jej „przegadanie", co zdarza się u przypadku choćby posądzania autora tekstu o grafomanię. Taki słowny mem ma za zadanie szybko i celnie podsumować, że użytkounik odbiera treść jako nudną, zbędną, a robi to w dwóch ruchach - kopiuj-wklej. Copypasta zatem to forma memetyczna, która:

- jest tekstem - z zasady dłuższym, czyli o objętości większej niż ok. 1000 znaków;

- jest czyimś autentycznym komentarzem, albo nosi znamiona autentyczności;

- jest w jakiś sposób zabauna - albo przez niepoprawną pisounię i błędy językowe, albo merytorycznie - przez treść;

- $\quad$ wklejona jest $u$ miejsce, $u$ którym nie powinna się znaleźć i gdzie jej użycie nie ma logicznego sensu;

${ }^{22}$ http://www.wykop.pl/wpis/7821458/coolstory-takbylo-copypasta-byloaledobre-zima-idzi/ [dostęp: 22.01.2015]. 
- jest łatwa do zdekodowania tylko dla pewnej części użytkouników, którzy szybko informują w komentarzach resztę odbiorców, że jest to tylko humorystyczny element i aby nie podejmowali dialogu z autorem copypasty.

Copypasta jest często intertekstualna na poziomie logicznym - jeżeli autor używa tej, u której mowa o „obrażaniu papieża Polaka”, oznacza to, że pragnie u ten sposób wyrazić brak dystansu swojego oponenta do komentowanej kwestii. Innymi słowy, jeżeli pod felietonem, w którym autor wyraża oburzenie danym zjawiskiem, znajdzie się tego typu copypasta, to pokazuje to negatywny stosunek do tegoż felietonu i zarzucanie mu braku dystansu czy poczucia humoru. Jest to forma memetyczna, która wirusowo zawładnęła internautami i - pomimo oczywistych kontrowersji wynikających z treści copypast - osiąga memetyczny sukces i jest wciąż powielana u najróżniejszych formach. Można ją zatem z powodzeniem nazwać „memem słounym”.

Memy, które pierwotnie stanowily formę żartobliwego, intertekstualnego opisywania rzeczywistości, zdają się powoli „ewoluować” i podążać w kierunku szeroko rozumianego infotainmentu, czyli informacji połączonej z rozrywką, bądź przekazanej w rozrywkowej formie. W Internecie można jednak napotkać na takie obrazki, które nie stanowią formy rozrywkowej w klasycznej definicji, niosą za to za sobą ładunek informacyjny - ważny na przykład ze społecznego punktu widzenia.

Jest to nietypowa forma memetyczna, o której koniecznie trzeba uspomnieć przy wymienianiu nowych zjawisk wirusowych. Memetyczny infotainment przypomina bowiem inicjatywy oddolnie pojawiające się u społeczeństuie; stanowi formę demaskacji czy pokazywania ludziom aspektów, o których nie mówi się głośno w mediach głównego nurtu. W sieci umieszczane są więc obrazki, które w prosty i klarowny sposób przedstawiają różne bieżące kwestie, na przykład polityczne.

Do Internetu trafiają zatem tego typu obrazki, jak przedstawiony na rycinie 1.

\title{
Uwaga Polaku!!!
}

\begin{abstract}
Koalicja rządząca (PO+PSL) przegłosowała 8 listopada w sejmie ustawę dopuszczającą obrót żywnością GMO w Polsce. Mimo tego, iż zdecydowana większość społeczeństwa uważa tą żywność za szkodliwą dla zdrowia. Mało tego ustawa nie narzuca obowiązku znakowania żywności GMO. Nie będziemy wiedzieć, czy kupowana żywność jest GMO, czy też nie. Wiele krajów Unii Europejskiej (m.in.Francja, Austria, Węgry, Włochy, Luksemburg Grecja, Niemcy, Bułgaria) oraz Szwajcaria zabroniło, na podstawie odpowiedniego uzasadnienia, upraw roślin genetycznie zmodyfikowanych. Jedno jest pewne, raz dopuszczona uprawa żywności GMO w Polsce, będzie nieodwracalna ze względu na skażenia transgeniczne pomiędzy roślinami GMO, a ekologicznymi. Nie da rady zakazać pszczołom zapylania między sąsiadującymi polami GMO i EKO, w efekcie rolnicy uprawiający żywność EKO, stracą certyfikaty $i$ będą zmuszeni do upraw GMO. Co ciekawe ustawa jakże ważna dla wszystkich Polaków przeszła w sejmie, praktycznie bez specjalnego rozgłosu w mediach. Jeżeli zależy Ci na tym co jesz Ty i twoi bliscy - udostępnij tą informację dalej.! DNO!!!!!
\end{abstract}

Rycina 1. Informacja o GMO

Źródło: http://i1.kwejk.pl/k/obrazki/2012/11/4074b3379b1afdfd6c32736a62283ae8_original.jpg [dostęp: 28.11.2016]. 
Obrazek nie nosi żadnych znamion humorystycznych, jest to - mimo zawartości tekstowej - wciąż format obrazka, przez co łatwiej jest kopiować go jako całość, niż przepisywać bądź szukać powierzchni na wklejenie go jako komentarz. Mem stanowi „głos ludu”, jako że któryś z użytkouników postanowił przedstawić bieżące wydarzenie polityczne w swoim świetle. Obrazek został umieszczony w serwisie Kwejk.pl jednym z najpopularniejszych serwisów w Polsce, obfitującym w memy i odwiedzanym przez miliony użytkowników dziennie. Ilustracja tekstowa doczekała się powieleń, przekazań i polubień, co uskazuje na zainteresowanie faktem żyuności GMO, o której mowa w tekście. Godny uwagi jest fakt, że zjawisko to spełnia wytyczne memu jako takiego (wirusowy obrazek, celem jest rozprzestrzenienie się), nie służy on jednak rozrywce, a raczej informowaniu społeczeństwa - rzucenie go na podatny grunt (środowisko, które dla rozrywki odwiedza duża ilość osób) może pomóc u szerzeniu informacji wśród osób, które z zasady nie czytują wiadomości bądź nie interesują się najnouszymi działaniami rządu.

Przykładów tego typu jest bardzo dużo. Można tu przedstawić róunież sytuację z protestami w Turcji w czerwcu 2013 roku, kiedy to rząd turecki wyłączył Facebooka, Twittera, a media były oszczędne w pokazywaniu rzetelnej informacji na temat wydarzeń, jakie rozgrywały się w tym kraju (ryc. 2).

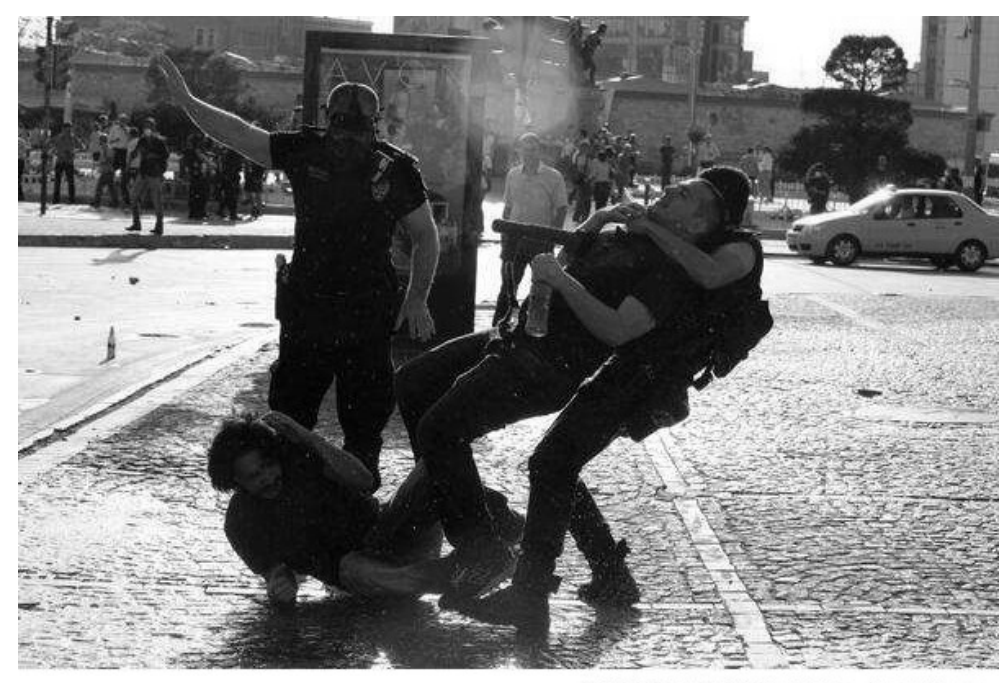

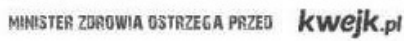

Rycina 2. Zamieszki w Turcji

Źródło: http://i1.kwejk.pl/k/obrazki/2013/06/7f84cf7ab9d13502b508f57b30ec2e27_original.jpg [dostęp: 28.11.2016].

Na uspomnianym portalu Kuejk została umieszczona galeria obrazków (na ryc. 2 przytoczono jeden z nich) okraszona komentarzem, że „świat milczy na ten temat”. Nawet jeżeli nie jest to do końca prawdą, a media pokazują wydarzenia u zależności 
od ukierunkowań politycznych i ich charakteru, to Internet staje się źródłem, które wymyka się z konwenansów i stara się być „pierwszy na miejscu”. Tego typu zjawisko nie do końca pasuje do ram infotainmentu (nie widać, żeby informacja miała charakter rozrywkowy), ale sam fakt umieszczenia informacji poważnej na portalu, który służy do zuyczajnej zabawy, wskazuje na nieszablonowość. Faktem jest, że taki obrazek odnosi sukces memetyczny zupełnie $w$ ten sam sposób, w jaki dzieje się to z klasycznym, żartobliwym memem. W obu przypadkach chodzi o to samo - informowanie i komentowanie rzeczywistości, tutaj jednak okazuje się, że może to mieć również charakter uświadamiający, poszerzający horyzonty odbiorców, a niebędący tylko „sztuką dla sztuki".

Przykłady takiego tworu można mnożyć - do sieci natychmiast trafiają obrazki informujące skrótowo, w prosty sposób, o nowych zmianach w ustawach (naturalnie tych niezbyt korzystnych dla przeciętnego człowieka), a także o najnowszych wydarzeniach z wolnościowej, niecenzurowanej perspektywy, która nierzadko stoi wręcz w opozycji do tego, co przekazują media głównego nurtu. Taka forma quasi-kontroli ze strony internautów jest fascynującym przejawem memetyki, która nie w każdym przypadku okazuje się bezcelowa i wyłącznie rozrywkowa.

Podsumowując, uszystkie $\mathrm{z}$ wymienionych form wirusowych $\mathrm{w}$ Internecie przejawiają zarówno cechy memu (są intertekstualne, dają się „przerabiać”, modyfikować, przetwarzać na własne potrzeby), jak i virala (choćby uspomnianą formę wideo czy bycie „sztuką dla sztuki”), jednak - jak w przypadku zjawiska fejmu - trudno dopasować je do kategorii uspomnianego memu czy virala. Nie można również traktować ich jako zbiorowe zjawisko ani grupować $w$ pomniejsze kategorie ze uzględu na znaczne różnice pomiędzy poszczególnymi zjawiskami - z logicznego punktu widzenia trudno jest porównywać popularność nastolatków z „opowieściami z dreszczykiem”, jak można określić omawiane creepypasty.

Faktem zaś jest, że uszystkie one osiągają memetyczny sukces i z jakiegoś powodu są uwielbiane przez internautów. Rozważania nad społeczeństwem informacyjnym i rosnącą bezrefleksyjnością użytkowników pokazują, że w istocie rzeczy można mówić o zjawisku „piątej władzy”, gdzie pozornie abstrakcyjne zjawiska mogą upływać w znacznym stopniu na rzeczywistość. Wszystkie te nowe formy komunikowania jednak czemuś służą - jak widać na podstawie przytoczonych przykładów, nie zawsze chodzi wyłącznie o rozrywkę. Analiza opisanych zjawisk w kontekście nauk o komunikowaniu pomoże odpowiedzieć na pytanie, czy zjawiska wirusowe są jedynie nową formą komunikowania, czy może stanowią narzędzie, które w przyszłości może okazać się silniejsze od mediów znanych do tej pory.

\section{Podsumowanie}

Z przeprowadzonej analizy można wysnuć kilka uniosków. Nadrzędnym jest ten, że zjawisko „piątej władzy” - traktowane w sposób ilościowy i jakościowy - ewidentnie 
istnieje. Zachodzi zatem potrzeba pogłębionych badań, które skupią się li tylko na nim. Potrzeba również więcej analiz konkretnych przypadków, a wreszcie - mierzalnych efektów, takich jak uybory parlamentarne czy inna forma, w której działania zainicjowane u sieci przez internautów mogłyby uydostać się nie tylko do mediów głównego nurtu, ale także zaczęłyby realnie upływać na kształtowanie się opinii publicznej. Same wartości, jakie generują zjawiska pod uspólnym terminem „piąta władza”, pokazują, że internauci naprawdę mają realną siłę oddziaływania. Skoro potrafią skrzyknąć się, żeby uratować chore dziecko albo odbić konia z rzeźni, to tym bardziej będą potrafili połączyć siły u ważniejszej sprawie. Takie zjawiska znane są od dawna - chodzi o uszelkie pospolite ruszenia. Do tej pory jednak trudno było o tak szybki efekt, jakim jest docieranie do setek tysięcy internautóu jednocześnie - owe „internetowe pospolite ruszenia" mogą odnieść spektakularny sukces w ogólnie rozumianym życiu publicznym.

\section{Bibliografia}

Blackmore S., Maszyna memowa, tłum. N. Radomski, Rebis, Poznań 2002.

Brodie R., Wirusy umysłu, tłum. P. Turski, Ravi, Warszawa 1997.

Dawkins R., Samolubny gen, tłum. M. Skoneczny, Prószyński i S-ka, Warszawa 2002.

Godzic W., Znani z tego, że są znani. Celebryci w kulturze tabloidów, Wydawnictua Akademickie i Profesjonalne, Warszawa 2007.

Grant G., Memetic Lexicon, tłum. własne, http://pespmc1.vub.ac.be/MEMLEX.html [dostęp: 23.04.2013].

http://ask.fm/lukaswaurzyniak [dostęp: 22.01.2015].

http://ask.fm/poziom [dostęp: 22.01.2015].

http://natemat.pl/71559,zamknijcie-portal-ask-fm-nie-chce-patrzec-na-smierc-kolejnych-dzieci-dramatyczny-apel-matki [dostęp: 22.01.2015].

http://pl.copypasta.wikia.com/wiki/Strona_g\%C5\%82\%C3\%B3wna [dostęp: 21.01.2015].

http://wwu.wykop.pl/wpis/4133273/masz-ty-w-ogole-rozum-i-godnosc-czlowieka-\%CA\%96humor/ [dostęp: 22.01.2015].

http://www.wykop.pl/wpis/7821458/coolstory-takbylo-copypasta-byloaledobre-zima-idzi/ [dostęp: 22.01.2015].

http://wuw.alexa.com/siteinfo/ask.fm [dostęp: 22.01.2015].

Litman M., FenoMEM, czyli charakterystyka internetowych memów, praca licencjacka napisana pod kierunkiem dr Magdaleny Hodalskiej, Instytut Dziennikarstwa i Komunikacji Społecznej Uniwersytetu Jagiellońskiego, Kraków 2013.

Niwiński T., Wprowadzenie: Kryzys umysłu [w:] R. Brodie, Wirus umysłu, tłum. P. Turski, Ravi, Warszawa 1997. 